Article

\title{
Energy Research, Sustainable Development and Applications in Sudan
}

\author{
Abdeen Omee ${ }^{1, *}$ \\ ${ }^{1}$ Energy Research Institute (ERI), Nottingham NG7 4EU, United Kingdom \\ E-Mails: abdeenomer2@yahoo.co.uk \\ * Author to whom correspondence should be addressed; Tel.: +00-44-115-9421480; Fax: +00-44-115- \\ 9421480
}

Received: 12 November 2013 / Accepted: 12 November 2013 / Published: 12 November 2013

\begin{abstract}
People will have to rely upon mineral oil for primary energy and this will go on for a few more decades. Other conventional sources of energy may be more enduring, but are not without serious disadvantages. The renewable energy resources are particularly suited for the provision of rural energy supplies. A major advantage of using the renewable energy sources is that equipment such as flat plate solar driers, wind machines, etc., can be constructed using local resources and with the advantage of local maintenance which can encourage local manufacturing that can give a boost to the building of small-scale rural based industries. This article gives a comprehensive review of energy sources, the environment and sustainable development in Sudan. It reviews the renewable energy technologies, energy efficiency systems, energy conservation scenarios, energy savings in greenhouses environment and other mitigation measures necessary to reduce climate change. This article gives some examples of small-scale energy converters, nevertheless it should be noted that small conventional, i.e., engines are currently the major source of power in rural areas and will continue to be so for a long time to come. There is a need for some further development to suit local conditions, to minimise spares holdings, to maximise interchangeability both of engine parts and of the engine application. Emphasis should be placed on full local manufacturing of some of the energy systems. It is concluded that renewable environmentally friendly energy must be encouraged, promoted, implemented and demonstrated by full-scale plan especially for use in remote rural areas of many developing nations.
\end{abstract}


Keywords: Renewable energy technologies, energy efficiency, sustainable development, emissions, environment.

\section{Introduction}

Power from natural resources has always had great appeal. Coal is plentiful, though there is concern about despoliation in winning it and pollution in burning it. Nuclear power has been developed with remarkable timeliness, but is not universally welcomed, construction of the plant is energy-intensive and there is concern about the disposal of its long-lived active wastes. Barrels of oil, lumps of coal, even uranium come from nature but the possibilities of almost limitless power from the atmosphere and the oceans seem to have special attraction. The wind machine provided an early way of developing motive power. The massive increases in fuel prices over the last years have however, made any scheme not requiring fuel appear to be more attractive and to be worth reinvestigation. In considering the atmosphere and the oceans as energy sources, the four main contenders are wind power, wave power, tidal and power from ocean thermal gradients. The sources to alleviate the energy situation in the world are sufficient to supply all foreseeable needs. Conservation of energy and rationing in some form will however have to be practised by most countries, to reduce oil imports and redress balance of payments positions. Meanwhile development and application of nuclear power and some of the traditional solar, wind and water energy alternatives must be set in hand to supplement what remains of the fossil fuels (Omer, 2009d).

The encouragement of greater energy use is an essential component of development. In the short-term, it requires mechanisms to enable the rapid increase in energy/capita, while in the long-term it may require the use of energy efficiency without environmental and safety concerns. Such programmes should as far as possible be based on renewable energy resources. Large-scale, conventional, power plant such as hydropower has an important part to play in development although it does not provide a complete solution. There is however an important complementary role for the greater use of small scale, rural based, power plants. Such plants can be employed to assist development since they can be made locally. Renewable resources are particularly suitable for providing the energy for such equipment and its use is also compatible with the long-term aims. In compiling energy consumption data one can categorise usage according to a number of different schemes:

- Traditional sector- industrial, transportation, etc.

- $\quad$ End-use- space heating, process steam, etc.

- Final demand- total energy consumption related to automobiles, to food, etc.

- Energy source- oil, coal, etc.

- Energy form at point of use- electric drive, low temperature heat, etc.

In this article a comprehensive review of green energies is given. This includes all the renewable energy technologies, energy efficiency system and other policies and measures necessary to reduce climate change. The connection between technical change, economic policies and the environment is of primary importance as observed by most governments in developing countries, whose attempts to 
attain food self-sufficiency have led them to take the measures that provide incentives for adoption of the Green Revolution Technology (Abdeen, 2008).

\section{Results and Discussion}

The increased availability of reliable and efficient energy services stimulates new development alternatives (Omer, 2009a). This article discusses the potential for such integrated systems in the stationary and portable power market in response to the critical need for a cleaner energy technology. Anticipated patterns of future energy use and consequent environmental impacts (acid precipitation, ozone depletion and the greenhouse effect or global warming) are comprehensively discussed in this paper. Throughout the theme, several issues relating to renewable energies, environment and sustainable development are examined from both current and future perspectives analyzed. It is concluded that renewable environmentally friendly energy must be encouraged, promoted, implemented and demonstrated by full-scale plan especially for use in remote rural areas. Globally, buildings are responsible for approximately $40 \%$ of the total world annual energy consumption. Most of this energy is for the provision of lighting, heating, cooling, and air conditioning. Increasing awareness of the environmental impact of $\mathrm{CO}_{2}$ and Nitrogen oxide $\left(\mathrm{NO}_{\mathrm{x}}\right)$ emissions and Chlorofluorocarbons (CFCs) triggered a renewed interest in environmentally friendly cooling, and heating technologies. Under the 1997 Montreal Protocol, governments agreed to phase out chemicals used as refrigerants that have the potential to destroy stratospheric ozone. It was therefore considered desirable to reduce energy consumption and decrease the rate of depletion of world energy reserves and pollution of the environment. One way of reducing building energy consumption is to design buildings, which are more economical in their use of energy for heating, lighting, cooling, ventilation and hot water supply. Passive measures, particularly natural or hybrid ventilation rather than airconditioning, can dramatically reduce primary energy consumption. However, exploitation of renewable energy in buildings and agricultural greenhouses can, also, significantly contribute towards reducing dependency on fossil fuels. Therefore, promoting innovative renewable applications and reinforcing the renewable energy market will contribute to preservation of the ecosystem by reducing emissions at local and global levels. This will also contribute to the amelioration of environmental conditions by replacing conventional fuels with renewable energies that produce no air pollution or greenhouse gases.

\subsection{Renewable Energy Potential}

There is strong scientific evidence that the average temperature of the earth's surface is rising. This is a result of the increased concentration of carbon dioxide and other Green House Gases (GHGs) in the atmosphere released by burning fossil fuels. This global warming will eventually lead to substantial changes in the world's climate, which will, in turn, have a major impact on human life and the built environment. Therefore, effort has to be made to reduce fossil energy use and to promote green energies, particularly in the building sector. Energy use reductions can be achieved by minimising the energy demand, by rational energy use, for example, by recovering heat and the use of more green energies and green energy technologies. This study was a step towards achieving that goal. The adoption of green or sustainable approaches to the way in which society is run is seen as an important strategy in finding a solution to the energy problem. The key factors to reducing and controlling 
Carbon dioxide $\left(\mathrm{CO}_{2}\right)$, which is the major contributor to global warming, are the use of alternative approaches to energy generation and the exploration of how these alternatives are used today and may be used in the future as green energy sources (Omer, 2009b). Even with modest assumptions about the availability of land, comprehensive fuel-wood farming programmes offer significant energy, economic and environmental benefits. These benefits would be dispersed in rural areas where they are greatly needed and can serve as linkages for further rural economic development. The developing nations as a whole would benefit from savings in foreign exchange, improved energy security, and socio-economic improvements. With a nine-fold increase in forest - plantation cover, a nation's resource base would be greatly improved. The international community would benefit from pollution reduction, climate mitigation, and the increased trading opportunities that arise from new income sources. The nontechnical issues, which have recently gained attention, include: (1) Environmental and ecological factors, e.g., carbon sequestration, reforestation and revegetation. (2) Renewables as a $\mathrm{CO}_{2}$ neutral replacement for fossil fuels. (3) Greater recognition of the importance of renewable energy, particularly modern biomass energy carriers, at the policy and planning levels. (4) Greater recognition of the difficulties of gathering good and reliable renewable energy data, and efforts to improve it. (5) Studies on the detrimental health efforts of biomass energy particularly from traditional energy users. Table 1 lists the energy sources available.

Table 1. Sources of energy

\begin{tabular}{|l|l|l|}
\hline Energy source & Energy carrier & Energy end-use \\
\hline Vegetation & Fuel-wood & $\begin{array}{l}\text { Cooking } \\
\text { Water heating } \\
\text { Building materials } \\
\text { Animal fodder preparation }\end{array}$ \\
\hline Oil & Kerosene & $\begin{array}{l}\text { Lighting } \\
\text { Ignition fires }\end{array}$ \\
\hline Dry cells & Dry cell batteries & $\begin{array}{l}\text { Lighting } \\
\text { Small appliances }\end{array}$ \\
\hline Muscle power & Animal power & $\begin{array}{l}\text { Transport } \\
\text { Land preparation for farming } \\
\text { Food preparation (threshing) }\end{array}$ \\
\hline Muscle power & Human power & $\begin{array}{l}\text { Transport } \\
\text { Land preparation for farming } \\
\text { Food preparation (threshing) }\end{array}$ \\
\hline
\end{tabular}

Currently the 'non-commercial' fuels wood, crop residues and animal dung are used in large amounts in the rural areas of developing countries, principally for heating and cooking; the method of use is highly inefficient. Table 2 presents some renewable applications. Table 3 lists the most important of energy needs while table 4 lists methods of energy conversion.

Considerations when selecting power plant include the following:

- Power level- whether continuous or discontinuous.

- Cost- initial cost, total running cost including fuel, maintenance and capital amortised over life.

- Complexity of operation, and maintenance and availability of spares.

- $\quad$ Life and suitability for local manufacture. 
The household wastes, i.e., for family of four persons, could provide $280 \mathrm{kWh} / \mathrm{yr}$ of methane, but with the addition of vegetable wastes from 0.2 ha or wastes from 1 ha growing a complete diet, about $1500 \mathrm{kWh} / \mathrm{yr}$ may be obtained by anaerobic digestion (Omer, 2009c). The sludge from the digester may be returned to the land. In hotter climates, this could be used to set up a more productive cycle (Figure 1). There is a need for greater attention to be devoted to this field in the development of new designs, the dissemination of information and the encouragement of its use. International and government bodies and independent organisations all have a role to play in renewable energy technologies. Society and industry in Europe and elsewhere are increasingly dependent on the availability of electricity supply and on the efficient operation of electricity systems. In the European Union (EU), the average rate of growth of electricity demand has been about $1.8 \%$ per year since 1990 and is projected to be at least $1.5 \%$ yearly up to 2030 (Omer, 2009c).

Table 2. Renewable applications

\begin{tabular}{|l|l|}
\hline Systems & Applications \\
\hline Water supply & Rain collection, purification, storage and recycling \\
Wastes disposal & Anaerobic digestion $\left(\mathrm{CH}_{4}\right)$ \\
Cooking & Methane \\
Food & Cultivate the 1 hectare plot and greenhouse for four people \\
Electrical demands & Wind generator \\
Space heating & Solar collectors \\
Water heating & Solar collectors and excess wind energy \\
Control system & Ultimately hardware \\
Building fabric & Integration of subsystems to cut costs \\
\hline
\end{tabular}

Table 3. Energy needs in rural areas

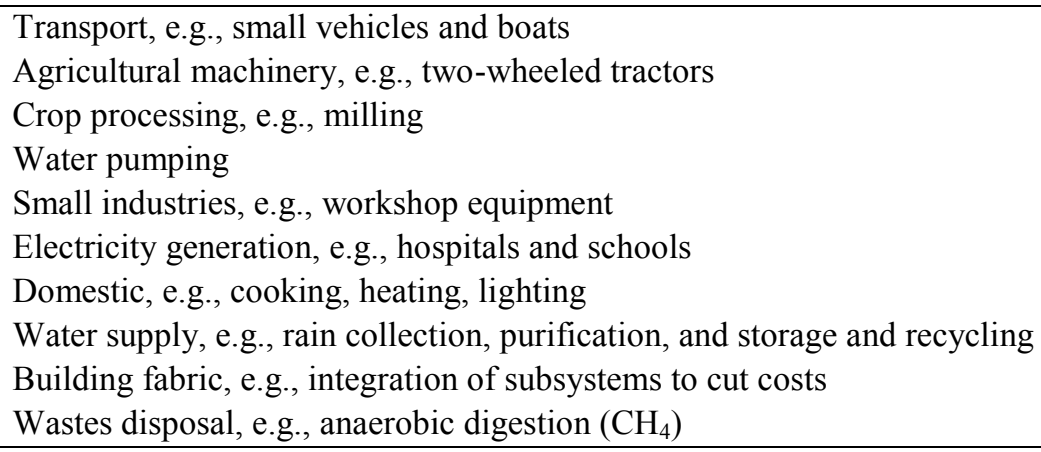

In the Sudan, electricity reaches only about $30 \%$ of the population, mainly in urban areas. Hence, a major problem for rural people is the inadequate supply of power for lighting, heating, cooking, cooling, water pumping, radio or TV communications and security services. Petroleum product supplies, including diesel, kerosene and LPG are irregular and often subject to sudden price increases. Because of the inadequate supply of these fuels, women trek great distances into the forest to collect fuelwood, charcoal and biomass residues from animal and agriculture, which account for more than half of total energy consumption. Most of this is utilised for cooking and heating water in rural and semi urban areas and by the urban poor. It is a need to provide alternative renewable energy sources to enhance women's participation in, and benefit from development. Household energy was the first 
energy sector that paid explicit attention to women and their energy needs. The contribution of women to environmental policy is largely ignored.

Table 4. Methods of energy conversion

\begin{tabular}{|l|l|}
\hline $\begin{array}{l}\text { Muscle power } \\
\text { Internal combustion engines } \\
\text { Reciprocating }\end{array}$ & Man, animals \\
& $\begin{array}{l}\text { Petrol- spark ignition } \\
\text { Diesel- compression ignition } \\
\text { Humphrey water piston }\end{array}$ \\
Rotating & Gas turbines \\
Heat engines & \\
Vapour (Rankine) & \\
Reciprocating & Steam engine \\
Rotating & Steam turbine \\
Gas Stirling (Reciprocating) & Steam engine \\
Gas Brayton (Rotating) & Steam turbine \\
Electron gas & Thermionic, thermoelectric \\
Electromagnetic radiation & Photo devices \\
Hydraulic engines & Wheels, screws, buckets, turbines \\
Wind engines (wind machines) & Vertical axis, horizontal axis \\
Electrical/mechanical & Dynamo/alternator, motor \\
\hline
\end{tabular}

Decision-making and policy formulation at all environmental levels, i.e., conservation, protection and rehabilitation and environmental management are more or less a male preserve. Women have been involved in promotion of appropriate energy technologies, primarily for rural populations over the past 15 years. Currently, distribution networks generally differ greatly from transmission networks, mainly in terms of role, structure (radial against meshed) and consequent planning and operation philosophies.

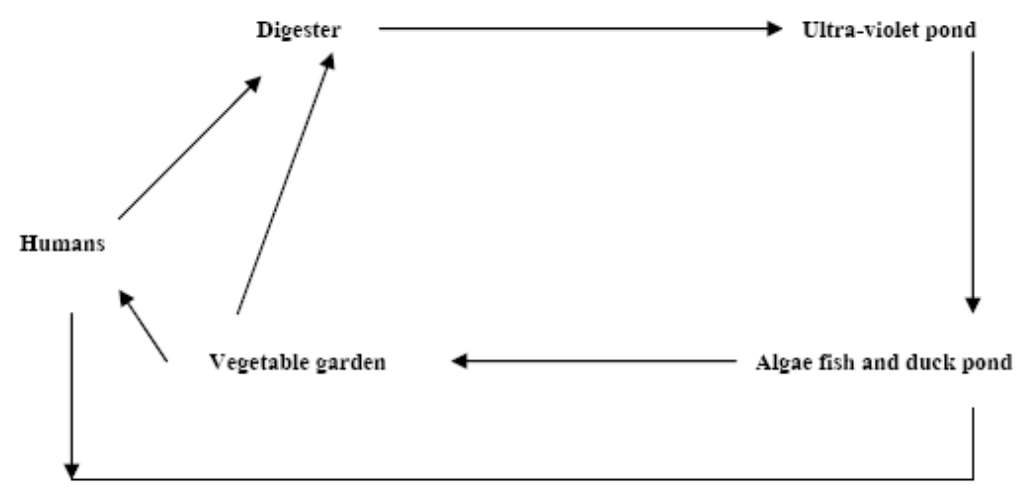

Figure 1. Biomass utilisation concepts

\subsection{Biogas Production}

Biogas is a generic term for gases generated from the decomposition of organic material. As the material breaks down, methane $\left(\mathrm{CH}_{4}\right)$ is produced as illustrated in Figure 2. Sources that generate biogas are numerous and varied. These include landfill sites, wastewater treatment plants and anaerobic digesters (Omer, 2009d). Landfills and wastewater treatment plants emit biogas from decaying waste. To date, the waste industry has focused on controlling these emissions to our environment and in some cases, tapping this potential source of fuel to power gas turbines, thus 
generating electricity (Omer, 2009d). The primary components of landfill gas are methane $\left(\mathrm{CH}_{4}\right)$, carbon dioxide $\left(\mathrm{CO}_{2}\right)$, and nitrogen $\left(\mathrm{N}_{2}\right)$. The average concentration of methane is $\sim 45 \%, \mathrm{CO}_{2}$ is $\sim 36 \%$ and nitrogen is $\sim 18 \%$ (Omer, and Yemen, 2001). Other components in the gas are oxygen $\left(\mathrm{O}_{2}\right)$, water vapour and trace amounts of a wide range of non-methane organic compounds (NMOCs). Landfill gasto-cogeneration projects present a win-win-win situation. Emissions of particularly damaging pollutant are avoided, electricity is generated from a free fuel and heat is available for use locally. Presently, Sudan uses a significant amount of kerosene, diesel, firewood, and charcoal for cooking in many rural areas. Biogas technology was introduced to Sudan in 1973 when GTZ designed a unit as a side-work of a project for water hyacinth control in central Sudan. Anaerobic digesters producing biogas (methane) offer a sustainable alternative fuel for cooking that is appropriate and economic in rural areas. In Sudan, there are currently over 200 installed biogas units, covering a wide range of scales appropriate to family, community, or industrial uses. The agricultural residues and animal wastes are the main sources of feedstock for larger scale biogas plants. There are in practice two main types of biogas plant that have been developed in Sudan; the fixed dome digester, which is commonly called the Chinese digester (120 units each with volumes $7-15 \mathrm{~m}^{3}$ ). The other type is with floating gasholder known as Indian digester ( 80 units each with volumes $5-10 \mathrm{~m}^{3}$ ). The solid waste from biogas plants adds economic value by providing valuable fertiliser as by products.

Table 5. Summary of material recycling practices in the construction sector (Robinson, 2007)

\begin{tabular}{|c|c|c|}
\hline $\begin{array}{l}\text { Construction and } \\
\text { demolition material }\end{array}$ & Recycling technology options & Recycling product \\
\hline Asphalt & $\begin{array}{l}\text { Cold recycling: heat generation; } \\
\text { Minnesota process; parallel drum } \\
\text { process; elongated drum; microwave } \\
\text { asphalt recycling system; finfalt; } \\
\text { surface regeneration }\end{array}$ & Recycling asphalt; asphalt aggregate \\
\hline Brick & Burn to ash, crush into aggregate & Slime burn ash; filling material; hardcore \\
\hline Concrete & Crush into aggregate & $\begin{array}{l}\text { Recycling aggregate; cement replacement; } \\
\text { protection of levee; backfilling; filter }\end{array}$ \\
\hline Ferrous metal & Melt; reuse directly & Recycled steel scrap \\
\hline Glass & $\begin{array}{l}\text { Reuse directly; grind to powder; } \\
\text { polishing; crush into aggregate; burn to } \\
\text { ash }\end{array}$ & $\begin{array}{l}\text { Recycled window unit; glass fibre; filling } \\
\text { material; tile; paving block; asphalt; recycled } \\
\text { aggregate; cement replacement; manmade soil }\end{array}$ \\
\hline Masonry & $\begin{array}{l}\text { Crush into aggregate; heat to } 900^{\circ} \mathrm{C} \text { to } \\
\text { ash }\end{array}$ & Thermal insulating concrete; traditional clay \\
\hline Non-ferrous metal & Melt & Recycled metal \\
\hline Paper and cardboard & Purification & Recycled paper \\
\hline Plastic & $\begin{array}{l}\text { Convert to powder by cryogenic } \\
\text { milling; clopping; crush into aggregate; } \\
\text { burn to ash }\end{array}$ & $\begin{array}{l}\text { Panel; recycled plastic; plastic lumber; } \\
\text { recycled aggregate; landfill drainage; asphalt; } \\
\text { manmade soil }\end{array}$ \\
\hline Timber & $\begin{array}{l}\text { Reuse directly; cut into aggregate; blast } \\
\text { furnace deoxidisation; gasification or } \\
\text { pyrolysis; chipping; moulding by } \\
\text { pressurising timber chip under steam } \\
\text { and water }\end{array}$ & $\begin{array}{l}\text { Whole timber; furniture and kitchen utensils; } \\
\text { lightweight recycled aggregate; source of } \\
\text { energy; chemical production; wood-based } \\
\text { panel; plastic lumber; geofibre; insulation } \\
\text { board }\end{array}$ \\
\hline
\end{tabular}




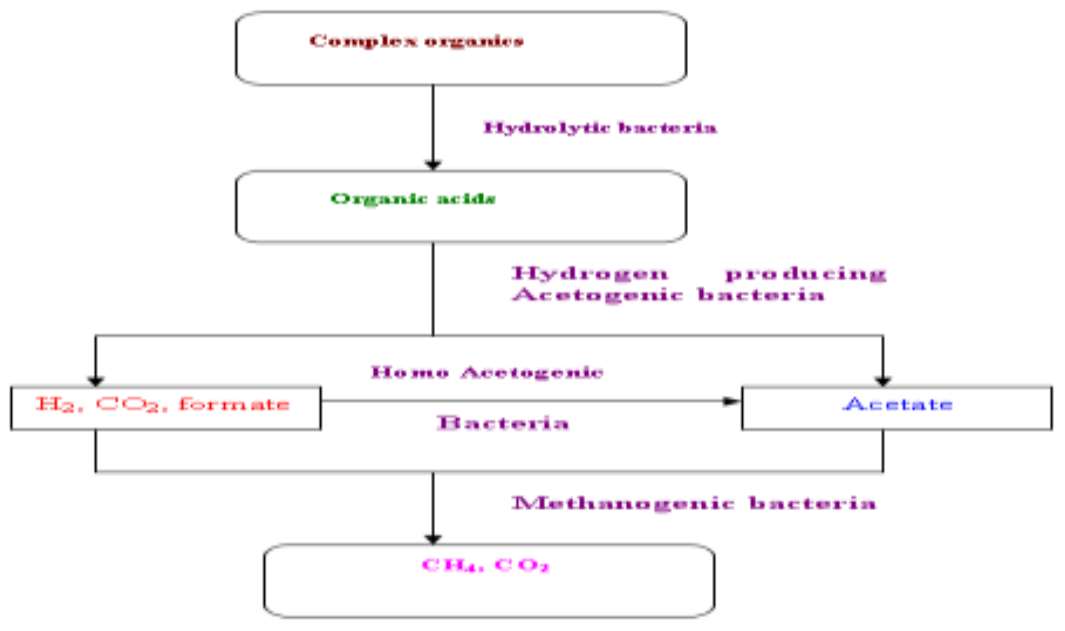

Figure 2. Biogas production process

\section{Energy Consumption}

Over the last decades, natural energy resources such as petroleum and coal have been consumed at high rates. The heavy reliance of the modern economy on these fuels is bound to end, due to their environmental impact, and the fact that conventional sources might eventually run out. The increasing price of oil and instabilities in the oil market led to search for energy substitute's way back in the early 1970s. In addition to the drain on resources, such an increase in consumption consequences, together with the increased hazards of pollution and the safety problems associated with a large nuclear fission programmes. A review of the potential range of recyclables is presented in Table 5. It would be equally unacceptable to suggest that the difference in energy between the developed and developing countries and prudent for the developed countries to move towards a way of life which, whilst maintaining or even increasing quality of life, reduce significantly the energy consumption per capita. Such savings can be achieved in a number of ways:

- Improved efficiency of energy use, for example better thermal insulation, energy recovery, and total energy.

- Conservation of energy resources by design for long life and recycling rather than the short life throwaway product.

- Systematic replanning of our way of life, for example in the field of transport.

Energy ratio is defined as the ratio of energy content of the food product/energy input to produce the food.

$$
\mathrm{Er}=\mathrm{Ec} / \mathrm{Ei}
$$

Where Er is the energy ratio, Ec is the energy content of the food product, and Ei is the energy input to produce the food.

Currently the non-commercial fuelwood, crop residues and animal dung are used in large amounts in the rural areas of developing countries, principally for heating and cooking and the method of use is highly inefficient. The fossil fuels are currently of great importance in the developing 
countries (Sudan is no exception). Geothermal and tidal energy are less important though, of course, will have local significance where conditions are suitable. Nuclear energy sources are options for completeness, but are not likely to make any effective contribution in the rural areas.

\subsection{Wave Power Conversion Devices}

The patent literature is full of devices for extracting energy from waves, i.e., floats, ramps, and flaps, covering channels (Swift-Hook, et al, 1975). Small generators driven from air trapped by the rising and falling water in the chamber of a buoy are in use around the world (Swift-Hook, et al, 1975). Wave power is one possibility that has been selected. Sudan has potential of waves at Red sea. Figure 3 shows the many other aspects that will need to be covered. A wave power programme would make a significant contribution to energy resources within a relatively short time and with existing technology. Wave energy has also been in the news recently. There is about 140 megawatts per mile available round British coasts. It could make a useful contribution people needs in the UK. Although very large amounts of power can be generated from the waves, it is important to consider how much power can be extracted. A few years ago only a few percent efficiency had been achieved. Recently, however, several devices have been studied which have very high efficiencies. Some form of storage will be essential on a second-to-second and minute-to-minute basis to smooth the fluctuations of individual waves and wave's packets but storage from one day to the next will certainly not be economical. This is why provision must be made for adequate standby capacity. A number of prospective areas have been identified by surveys and studies carried for exploration of minihydropower resources in Sudan. Mini and micro hydro can be utilised or being utilised in Sudan in two ways:

- Using the water falls from $1 \mathrm{~m}$ to $100 \mathrm{~m}$; energy can be generated, and small power can be generated up to $100 \mathrm{~kW}$.

- Using the current flow of the Nile water i.e., the speed of the Nile water. The water speed can be used to run the river turbines (current river turbines), and then water can be pumped from the Nile to the riverside farms. There are more than 200 suitable sites for utilisation of current river turbines along the Blue Nile and the main Nile.

The increased availability of reliable and efficient energy services stimulates new development alternatives. Anticipated patterns of future energy use and consequent environmental impacts (acid precipitation, ozone depletion and the greenhouse effect or global warming) are comprehensively discussed in this paper. Throughout the theme several issues relating to renewable energies, environment and sustainable development are examined from both current and future perspectives. It is concluded that renewable environmentally friendly energy must be encouraged, promoted, implemented and demonstrated by full-scale plan especially for use in remote rural areas. Globally, buildings are responsible for approximately $40 \%$ of the total world annual energy consumption. Most of this energy is for the provision of lighting, heating, cooling, and air conditioning. Increasing awareness of the environmental impact of $\mathrm{CO}_{2}$ and $\mathrm{NO}_{\mathrm{x}}$ emissions and $\mathrm{CFCs}$ triggered a renewed interest in environmentally friendly cooling, and heating technologies. The main advantages are related to energy, agriculture and environment problems, are foreseeable both at regional level and at worldwide level and can be summarised as follows: 
- Reduction of dependence on import of energy and related products.

- Reduction of environmental impact of energy production (greenhouse effect, air pollution, and waste degradation).

- Substitution of food crops and reduction of food surpluses and of related economic burdens, utilisation of marginal lands and of set aside lands.

- Reduction of related socio-economic and environmental problems (soil erosion, urbanisation, landscape deterioration, etc.), and development of new know-how and production of technological innovation.

\subsection{Ethanol production}

Alternative fuels were defined as methanol, ethanol, natural gas, propane, hydrogen, coalderived liquids, biological material and electricity production (Sims, 2007). The fuel pathways currently under development for alcohol fuels are shown in Figure 4. The production of agricultural biomass and its exploitation for energy purposes can contribute to alleviate several problems, such as the dependence on import of energy products, the production of food surpluses, the pollution provoked by the use of fossil fuels, the abandonment of land by farmers and the connected urbanisation. Biomass is not at the moment competitive with mineral oil, but, taking into account also indirect costs and giving a value to the aforementioned advantages, public authorities at national and international level can spur its production and use by incentives of different nature. In order to address the problem of inefficiency, research centres around the world have investigated the viability of converting the resource to a more useful form, namely solid briquettes and fuel gas (Sims, 2007) (Figure 5).

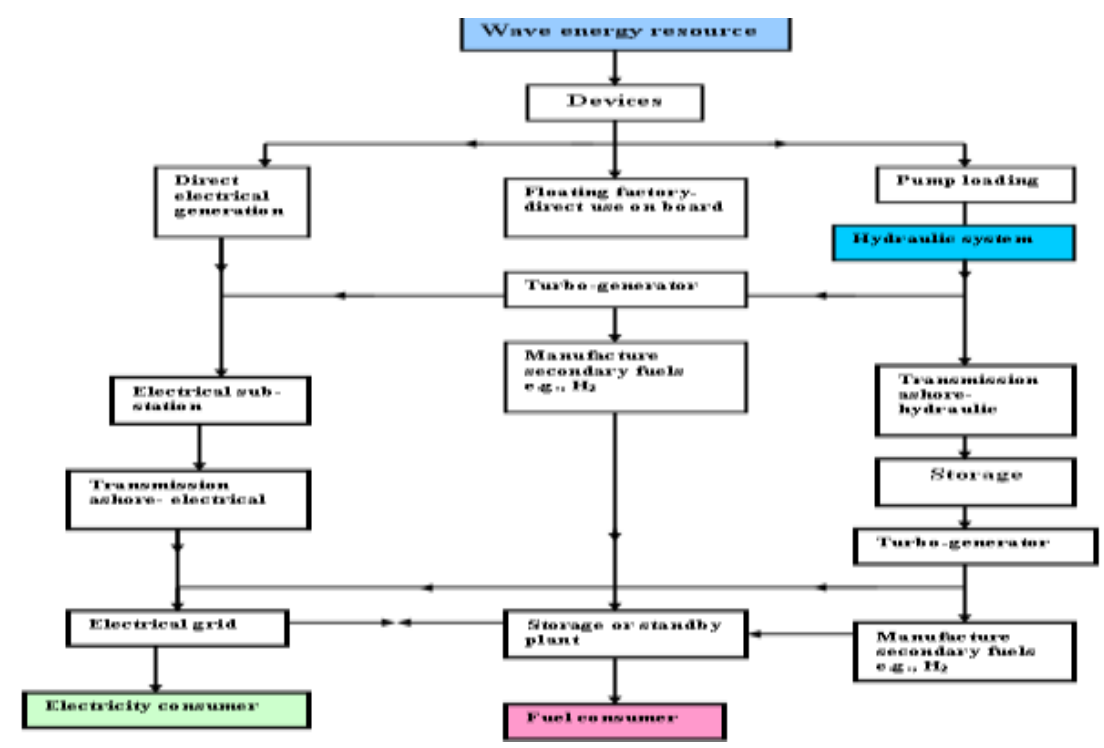

Figure 3. Possible systems for exploiting wave power, each element represents an essential link in the chain from sea waves to consumer

Biomass resources play a significant role in energy supply in all developing countries. Biomass resources should be divided into residues or dedicated resources, the latter including firewood and charcoal can also be produced from forest residues. Ozone $\left(\mathrm{O}_{3}\right)$ is a naturally occurring molecule that consists of three oxygen atoms held together by the bonding of the oxygen atoms to each other. The effects of the chlorofluorocarbons (CFCs) molecule can last for over a century. It is a common 
misconception that the reason for recycling old fridge is to recover the liquid from the cooling circuit at the back of the unit. The insulating foams used inside some fridges act as sinks of CFCs- the gases having been used as blowing agents to expand the foam during fridge manufacture. Although the use of ozone depleting chemicals in the foam in fridges has declined in the West, recyclers must consider which strategy to adopt to deal with the disposal problem they still present each year. It is common practice to dispose of this waste wood in landfill where it slowly degraded and takes up valuable void space. This wood is a good source of energy and is an alternative to energy crops. Agricultural wastes are abundantly available globally and can be converted to energy and useful chemicals by a number of microorganisms.

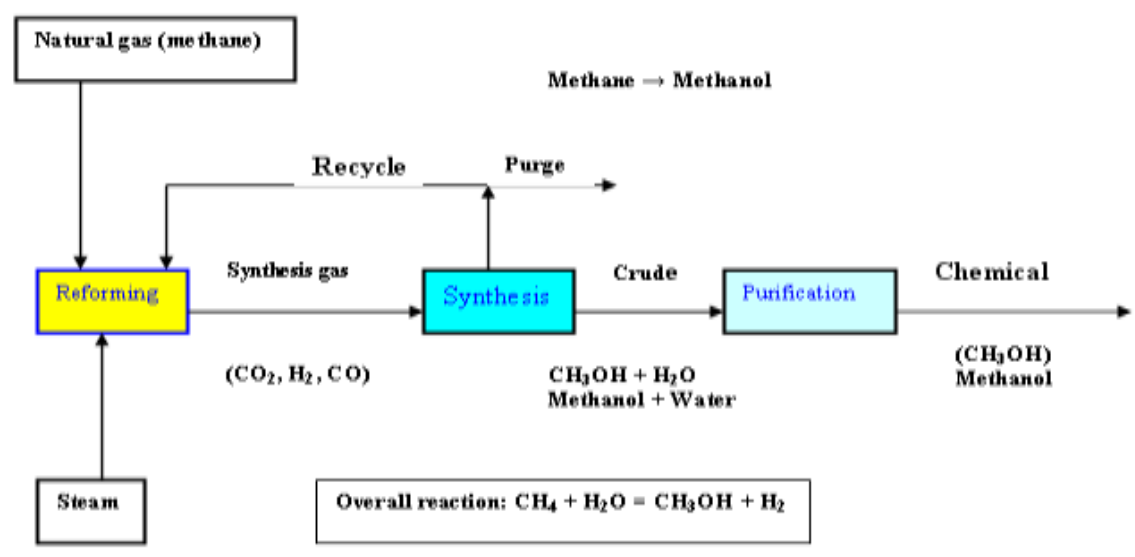

Figure 4. Schematic process flowsheet

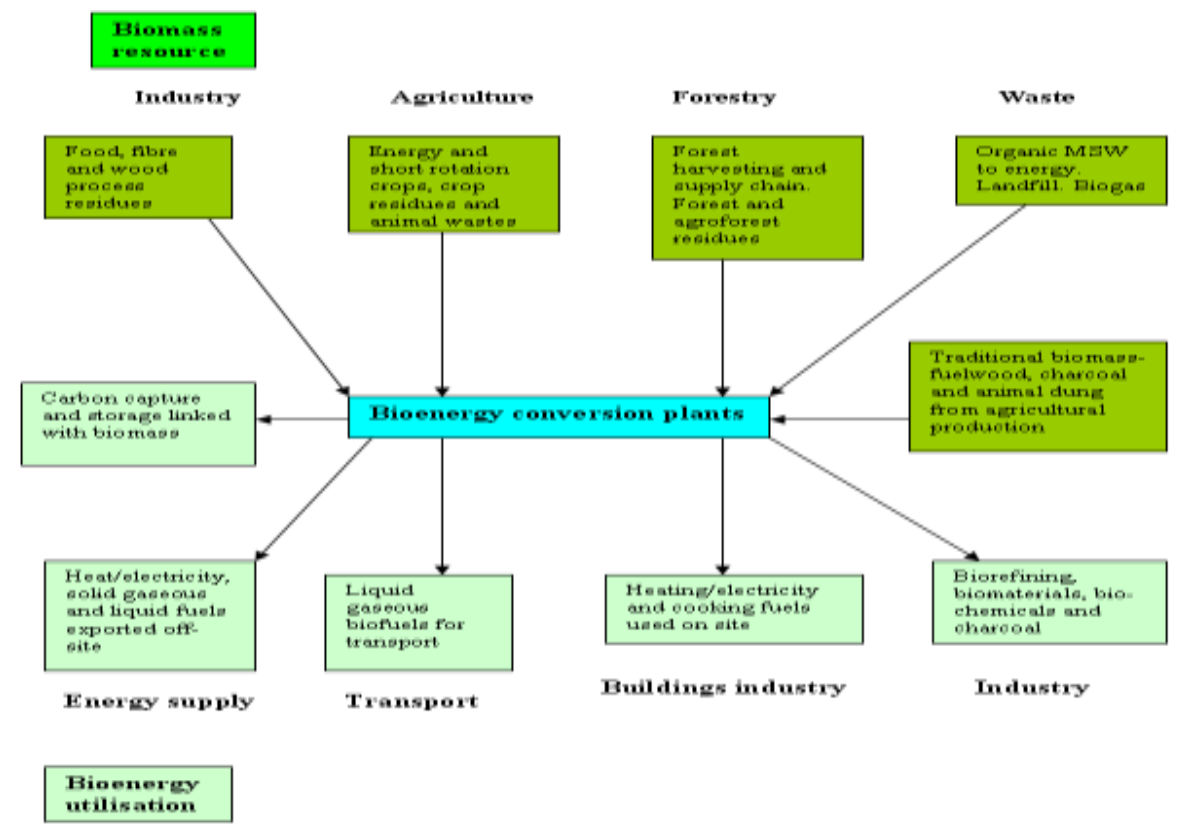

Figure 5. Biomass resources from several sources is converted into a range of products for use by transport, industry and building sectors (Sims, 2007)

The success of promoting any technology depends on careful planning, management, implementation, training and monitoring. Main features of gasification project are:

- Networking and institutional development/strengthening. 
- Promotion and extension.

- Construction of demonstration projects.

- $\quad$ Research and development, and training; and monitoring.

\subsection{Biomass CHP}

Combined heat and power (CHP) installations are quite common in greenhouses, which grow high-energy, input crops (e.g., salad vegetables, pot plants, etc.). Scientific assumptions for a shortterm energy strategy suggest that the most economically efficient way to replace the thermal plants is to modernise existing power plants to increase their energy efficiency and to improve their environmental performance. However, utilisation of wind power and the conversion of gas-fired CHP plants to biomass would significantly reduce the dependence on imported fossil fuels. Although a lack of generating capacity is forecasted in the long-term, utilisation of the existing renewable energy potential and the huge possibilities for increasing energy efficiency are sufficient to meet future energy demands in the short-term. A total shift towards a sustainable energy system is a complex and long process, but is one that can be achieved within a period of about 20 years. Implementation will require initial investment, long-term national strategies and action plans. However, the changes will have a number of benefits including: a more stable energy supply than at present and major improvement in the environmental performance of the energy sector, and certain social benefits. A national vision (Omer, 2009d) used a methodology and calculations based on computer modelling that utilised:

- Data from existing governmental programmes, and assumptions for future economy growth.

- Potential renewable energy sources and energy efficiency improvements.

- Information from studies and surveys on the recent situation in the energy sector.

In addition to realising the economic potential identified by the National Energy Savings Programme, a long-term effort leading to a 3\% reduction in specific electricity demand per year after 2020 is proposed. This will require: further improvements in building codes, and continued information on energy efficiency. Methane is a primary constituent of landfill gas (LFG) and a potent greenhouse gas (GHS) when released into the atmosphere. Globally, landfills are the third largest anthropogenic emission source, accounting for about $13 \%$ of methane emissions or over 818 million tones of carbon dioxide equivalent $\left(\mathrm{MMTCO}_{2} \mathrm{e}\right)$ (Brain, and Mark 2007) as shown in Figures 6-7.

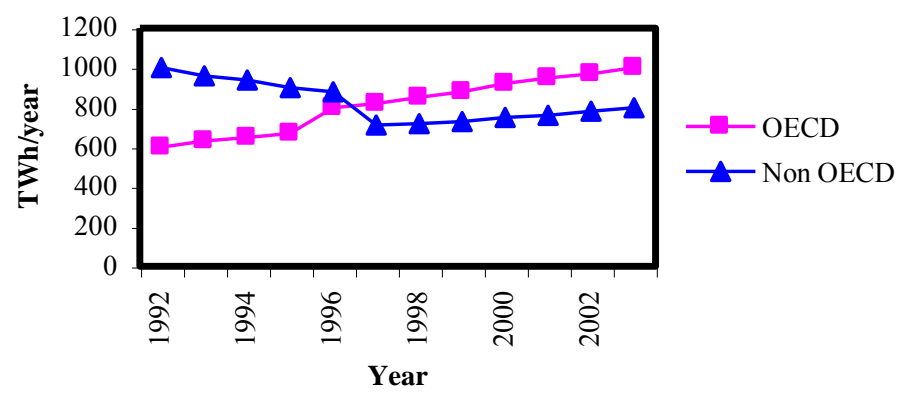

Figure 6. Global CHP trends from 1992-2003 (IEA, 2007) 


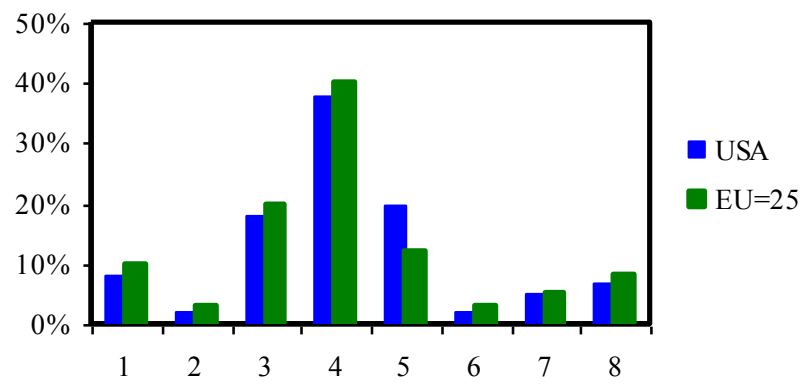

1 Food, 2 Textile, 3 Pulp \& paper, 4 Chemicals, 5 Refining, 6 Minerals, 7 Primary metals, and 8 others

Figure 7. Distribution of industrial CHP capacity in the EU and USA (IEA, 2007)

\subsection{Geothermal energy}

Geothermal steam has been used in volcanic regions in many countries to generate electricity. The use of geothermal energy involves the extraction of heat from rocks in the outer part of the earth. It is relatively unusual for the rocks to be sufficiently hot at shallow depth for this to be economically attractive. Virtually all the areas of present geothermal interest are concentrated along the margins of the major tectonic plates, which form the surface of the earth. The forced or natural circulation of water through permeable hot rock conventionally extracts heat. World capacity of geothermal energy is growing at a rate of $2.5 \%$ per year from a 2005 level of $28.3 \mathrm{GW}$ (Rawlings, 1999). The GSHPs account for approximately $54 \%$ of this capacity almost all of it in the North America and Europe (Rawlings, 1999). The involvement of the UK is minimal with less than $0.04 \%$ of world capacity and yet is committed to substantial reduction in carbon emission beyond the $12.5 \%$ Kyoto obligation to be achieved by 2012. The GSHPs offer a significant potential for carbon reduction and it is therefore expected that the market for these systems will rise sharply in the UK in the immediate years ahead given to low capacity base at present. Heat generation within the earth is approximately $2700 \mathrm{GW}$, roughly an order of magnitude greater than the energy associated with the tides but about four orders less than that received by the earth from the sun (Oxburgh, 1975). Temperature distributions within the earth depend on:

- The abundance and distribution of heat producing elements within the earth.

- The mean surface temperature (which is controlled by the ocean/atmosphere system).

- The thermal properties of the earth's interior and their lateral and radial variation.

- Any movements of fluid or solid rock materials occurring at rates of more than a few millimetres per year.

Of these four factors the first two are of less importance from the point of view of geothermal energy. Mean surface temperatures range between $0-30^{\circ} \mathrm{C}$ and this variation has a small effect on the useable enthalpy of any flows of hot water. Although radiogenic heat production in rocks may vary by three orders of magnitude, there is much less variation from place to place in the integrated heat production with depth. The latter factors, however, are of great importance and show a wide range of variation. Their importance is clear from the relationship: 


$$
\beta=q / k
$$

Where: $\beta$ is the thermal gradient for a steady state $\left({ }^{\circ} \mathrm{C} / \mathrm{km}\right), \mathrm{q}$ is the heat flux $\left(10^{-6} \mathrm{cal} \mathrm{cm}^{-2} \mathrm{sec}^{-1}\right)$ and $\mathrm{k}$ is the thermal conductivity (cal cm${ }^{-1} \mathrm{sec}^{-1}{ }^{\circ} \mathrm{C}^{-1}$ ).

The first requirement of any potential geothermal source region is that $\beta$ being large, i.e., that high rock temperatures occur at shallow depth. Beta will be large if either $\mathrm{q}$ is large or $\mathrm{k}$ is small or both. By comparison with most everyday materials, rocks are poor conductors of heat and values of conductivity may vary from $2 \times 10^{-3}$ to $10^{-2} \mathrm{cal} \mathrm{cm}^{-1} \mathrm{sec}^{-1}{ }^{\circ} \mathrm{C}^{-1}$. The mean surface heat flux from the earth is about 1.5 heat flow units $\left(1 \mathrm{HFU}=10^{-6} \mathrm{cal} \mathrm{cm}^{-2} \mathrm{sec}^{-1}\right)(\mathrm{Oxburgh}, 1975)$. Rocks are also very slow respond to any temperature change to which they are exposed, i.e., they have a low thermal diffusivity:

$$
\mathrm{K}=\mathrm{k} / \rho \mathrm{C}_{\mathrm{p}}
$$

Where:

$\mathrm{K}$ is thermal diffusivity; $\rho$ and $\mathrm{C}_{\mathrm{p}}$ are density and specific heat respectively.

These values are simple intended to give a general idea of the normal range of geothermal parameters (Table 6). In volcanic regions, in particular, both $q$ and $\beta$ can vary considerably and the upper values given are somewhat nominal.

Table 6. Values of geothermal parameters

\begin{tabular}{|l|l|l|l|}
\hline Parameter & Lower & Average & Upper \\
\hline $\mathrm{q}(\mathrm{HFU})$ & 0.8 & 1.5 & 3.0 (non volcanic) $\approx 100$ (volcanic) \\
$\mathrm{k}=\mathrm{cal} \mathrm{cm}^{-2} \mathrm{sec}^{-1}{ }^{\circ} \mathrm{C}^{-1}$ & $2 \times 10^{-3}$ & $6 \times 10^{-3}$ & $12 \times 10^{-3}$ \\
$\beta={ }^{\circ} \mathrm{C} / \mathrm{km}$ & 8 & 20 & 60 (non volcanic) $\approx 300$ (volcanic) \\
\hline
\end{tabular}

\subsection{Landfill gas}

Landfill gas (LFG) is currently extracted at over 1200 landfills worldwide for a variety of energy purposes (Table 7), such as:

- Creating pipeline quality gas or an alternative fuel for vehicles.

- Processing the LFG to make it available as an alternative fuel to local industrial or commercial customers.

- Generation of electricity with engines, turbines, micro-turbines and other emerging technologies.

In terms of solid waste management policy, many NGOs have changed drastically in the past ten years from a mass production and mass consumption society to 'material-cycle society' (Abdeen, 2008). In addition to national legislation, municipalities are legally obliged to develop a plan for handling the municipal solid waste (MSW) generated in administrative areas. 
Table 7. Types of LFG implemented recently worldwide

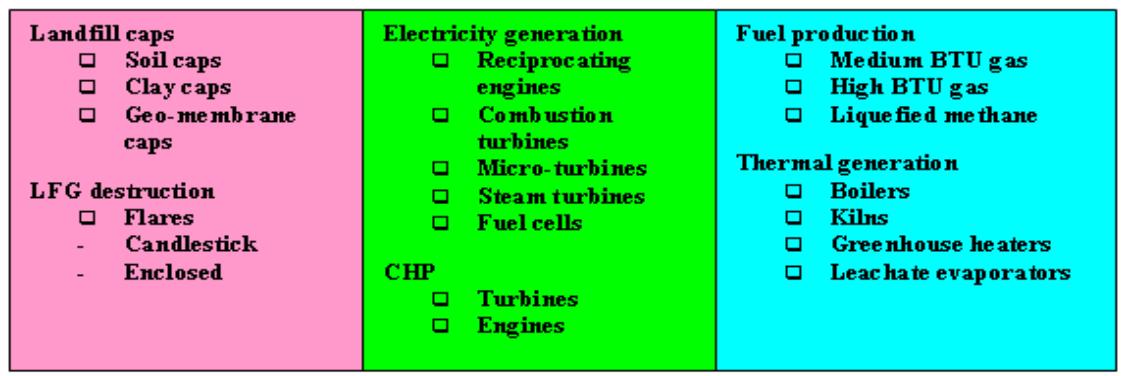

\subsection{Greenhouses environment}

Greenhouse cultivation is one of the most absorbing and rewarding forms of gardening for anyone who enjoys growing plants. The enthusiastic gardener can adapt the greenhouse climate to suit a particular group of plants, or raise flowers, fruit and vegetables out of their natural season. The greenhouse can also be used as an essential garden tool, enabling the keen amateur to expand the scope of plants grown in the garden, as well as save money by raising their own plants and vegetables. There was a decline in large private greenhouses during the two world wars due to a shortage of materials for their construction and fuel to heat them. However, in the 1950s mass-produced, small greenhouses became widely available at affordable prices and were used mainly for raising plants (John, 1993). Also, in recent years, the popularity of conservatories attached to the house has soared. Modern double-glazing panels can provide as much insulation as a brick wall to create a comfortable living space, as well as provide an ideal environment in which to grow and display tender plants.

Throughout the world urban areas have increased in size during recent decades. About $50 \%$ of the world's population and approximately $76 \%$ in the more developed countries are urban dwellers (UN, 2001). Even though there is an evidence to suggest that in many 'advanced' industrialised countries there has been a reversal in the rural-to-urban shift of populations, virtually all population growth expected between 2000 and 2030 will be concentrated in urban areas of the world. With an expected annual growth of $1.8 \%$, the world's urban population will double in 38 years (UN, 2001). This represents a serious contributing to the potential problem of maintaining the required food supply. Inappropriate land use and management, often driven by intensification resulting from high population pressure and market forces, is also a threat to food availability for domestic, livestock and wildlife use. Conversion to cropland and urban-industrial establishments is threatening their integrity. Improved productivity of peri-urban agriculture can, therefore, make a very large contribution to meeting food security needs of cities as well as providing income to the peri-urban farmers. Hence, greenhouses agriculture can become an engine of pro-poor 'trickle-up' growth because of the synergistic effects of agricultural growth such as (UN, 2001): 
- Increased productivity increases wealth and intensification drives rural non-farm enterprise and employment.

- Intensification by small farmers raises the demand for wage labour more than by larger farmers.

- Alleviation of rural and peri-urban poverty is likely to have a knock-on decrease of urban poverty.

The main reasons why it is vital for greenhouses planners and designers to develop a better understanding of greenhouses in high-density housing can be summarised as follows (WCED, 1987):

- Pressures to return to a higher density form of housing, and the requirement to provide more sustainable food.

- The urgent need to regenerate the existing, and often decaying, houses built in the higher density, high-rise form, much of which is now suffering from technical problems.

\subsubsection{Types of greenhouses}

Greenhouses vary considerably in their shapes and internal dimensions. Traditional greenhouses have straight sides, which allow the maximum use of internal space, and are ideal for climbers (Herath, 1985). On the other hand, greenhouses with sloping sides have the advantage of allowing the greatest penetration of sunlight, even during winter (Herath, 1985). The low winter sun striking the glass at $90^{\circ} \mathrm{C}$ lets in the maximum amount of light. Where the sun strikes the glass at a greater or lesser angle, a proportion of the light is reflected away from greenhouse. Sloping sides, also, offer less wind resistance than straight sides and therefore, less likely to be damaged during windy weather. This type of greenhouse is most suitable for short winter crops, such as early spring lettuce, and flowering annuals from seed, which do not require much headroom. However, there are several designs of greenhouses, based on dimensions, orientation and function. The following three options are the most widely used:

- A ready-made design

- A designed, which is constructed from a number of prefabricated modules

- A bespoke design

\subsubsection{Construction materials}

Different materials are used for the different parts. However, wood and aluminum are the two most popular materials used for small greenhouses. Steel is used for larger structures and UPVC for conservatories (Jonathon, 1991).

\subsubsection{Ground radiation}

Reflection of sunrays is mostly used for concentrating them onto reactors of solar power plants. Enhancing the insolation for other purposes has, so far, scarcely been used. Several years ago, application of this principle for increasing the ground irradiance in greenhouses, glass covered extensions in buildings, and for illuminating northward facing walls of buildings was proposed (Achard and Gicqquel, 1986). Application of reflection of sun's rays was motivated by the fact that 
ground illuminance/irradiance from direct sunlight is of very low intensity in winter months, even when skies are clear, due to the low incident angle of incoming radiation during most of the day. This is even more pronounced at greater latitudes. Large-scale, conventional, power plant such as hydropower has an important part to play in development. It does not, however, provide a complete solution. There is an important complementary role for the greater use of small scale, rural based, power plant. Such plant can be used to assist development since it can be made locally using local resources, enabling a rapid built-up in total equipment to be made without a corresponding and unacceptably large demand on central funds. Renewable resources are particularly suitable for providing the energy for such equipment and its use is also compatible with the long-term aims. It is possible with relatively simple flat plate solar collectors (Figure 8) to provide warmed water and enable some space heating for homes and offices which is particularly useful when the buildings are well insulated and thermal capacity sufficient for the carry over of energy from day to night is arranged. It is possible with relatively simple flat plate solar collectors (Figure 11) to provide warmed water and enable some space heating for homes and offices.

\subsubsection{Greenhouse environment}

It has been known for long time now that urban centres have mean temperatures higher than their less developed surroundings. The urban heat increases the average and peak air temperatures, which, in turn, affect the demand for heating and cooling. Higher temperatures can be beneficial in the heating season, lowering fuel use, but they exacerbate the energy demand for cooling in summer time. In temperate climates neither heating nor cooling may dominate the fuel use in a building, and the balance of the effect of the heat is less.

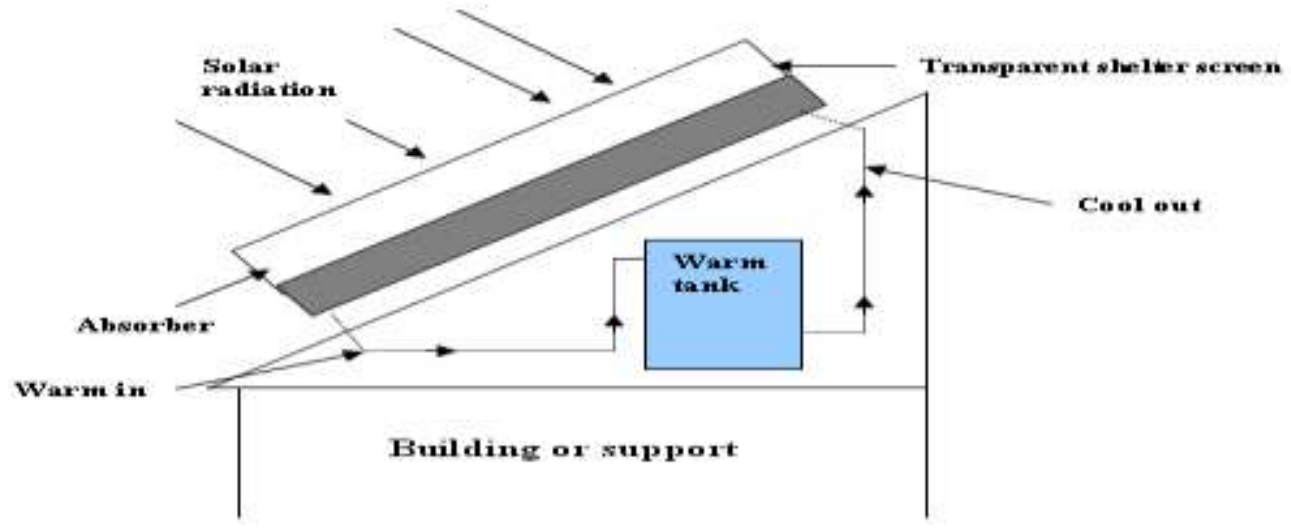

Figure 8. Solar heaters for hot water

The solar gains, however, would affect the energy consumption. Therefore, lower or higher percentage of glazing, or incorporating of shading devices might affect the balance between annual heating and cooling load. As the provision of cooling is expensive with higher environmental cost, ways of using innovative alternative systems like mop fans will be appreciated. Indeed, considerable research activities have been devoted to the development of alternative methods of refrigeration and air-conditioning. The mop fan is a novel air-cleaning device that fulfils the functions of de-dusting of gas streams, removal of gaseous contaminations from gas streams and 
gas circulation (Erlich, 1991). Hence, the mop fan seems particularly suitable for applications in industrial, agricultural and commercial buildings and greenhouses.

Indoor conditions are usually fixed by comfort conditions, with air temperatures ranging from $15^{\circ} \mathrm{C}$ to $27^{\circ} \mathrm{C}$, and relative humidities ranging from $50 \%$ to $70 \%$ (Abdeen, 2008). The system performance (COP) is defined as the ration between the cooling effect in the greenhouse and the total amount of air input to the mop fan. Hence,

$$
\mathrm{COP}=\text { cooling delivered/air input to the mop fan }
$$

Therefore, system performance (COP) varies with indoor and outdoor conditions. A lower ambient temperature and a lower ambient relative humidity lead to a higher COP. This means that the system will be, in principle, more efficient in colder and drier climates. The effect of indoor (greenhouse) conditions and outdoor (ambient) conditions (temperature and relative humidity) on system performance is illustrated in Figure 9.

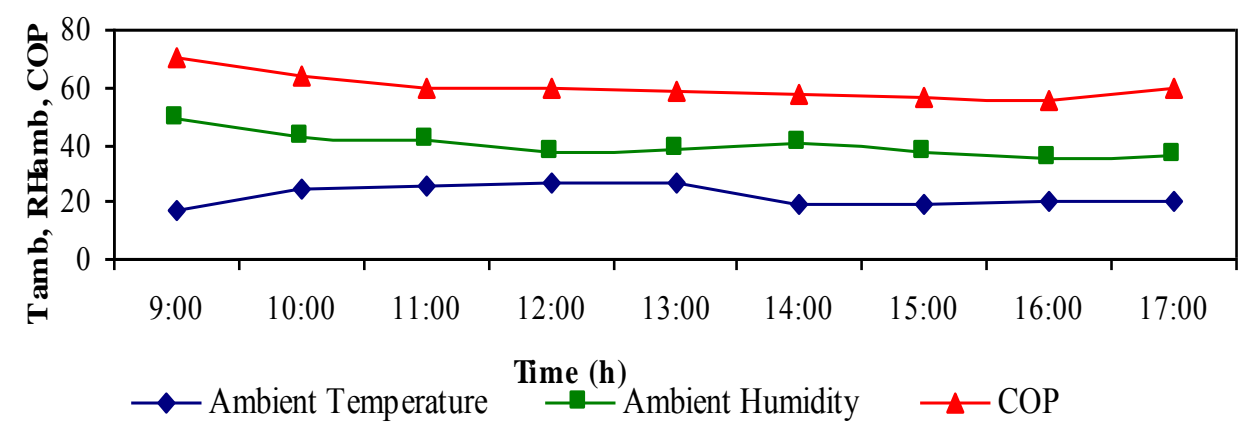

Figure 9. Ambient temperature, relative humidity and COP

\subsection{Wind Energy Potential}

The use of wind as a source of power has a long history. Wind power has been used in the past for water pumping, corn grinding, and provision for power for small industries. In areas of low population density where implementation of a central power system would be uneconomical, the decentralised utilisation of wind energy can provide a substantial contribution to development (Omer, 1997; Omer, 1998). The use of the wind machine is divided into two; one is the use of small-scale wind machines for water pumping or electricity generation, and the other is the use of large-scale wind machines for generating electricity (big wind machines or wind farms). However, the wind machine can be used for pumping water, electricity generation or any other task. A programme of wind power for generating electricity as well as for pumping water appears to be attractive for rural development, e.g., lights, radios, televisions. Wind electric generators can be utilised to meet the power requirements of isolated settlements. Wind energy is found to match well with the demand pattern of the loads, high load during the day for illumination. Wind energy has considerable resources in Sudan where the annual average wind speeds exceeds $5 \mathrm{~ms}^{-1}$ (at $10 \mathrm{~m}$ height) in the most parts north latitude $12^{\circ} \mathrm{N}$ (at the coastal area along the Red Sea), and along the Nile valley (from Wadi Halfa to Khartoum, and south of Khartoum covering the El Gezira area). The southern regions have the poorest potential 
because of the prevailing low wind speeds. Many designs of wind machines have been suggested and built in Sudan as shown in Table (8).

In Sudan, wind energy is today mainly used for water pumping. Wind has not yet been significantly exploited for power generation. Experience in wind energy in Sudan was started since 1950's, where 250 wind pumps from Australian government, had been installed in El Gezira Agricultural Scheme (Southern Cross Wind Pumps). These were gradually disappeared due to a lack of spare parts and maintenance skills combined with stiff competition from relatively cheep diesel pumps. However, the government has recently begun to recognize the need to reintroduce wind pump technology to reduce the country's dependence on foreign oil. This increases economic security, given high and/or fluctuating oil prices, and it helps to reduce the trade deficit. Using wind power also allows for pumping in rural areas where transportation of oil might be difficult.

In the last 15 years the Energy Research Institute (ERI) installed 15 Consultancy Services Wind Energy Developing Countries (CWD $5000 \mathrm{~mm}$ diameter) wind pumps around Khartoum area, Northern state, and Eastern state. Now ERI with cooperation of Sudanese Agricultural Bank (SAB) introduced 60 wind pumps to be use for water pumping in agricultural schemes, but not yet manufactured due to lack of financial support.

Table 8. Number of wind pumps installed for irrigation purpose in Sudan

\begin{tabular}{|l|l|}
\hline Location & Number of pumps \\
\hline Tuti island & 2 \\
\hline Jebel Aulia & 1 \\
\hline Soba & 4 \\
\hline Shambat & 4 (one was locally manufactured) \\
\hline Toker (eastern Sudan) & 2 (both locally manufactured) \\
\hline Karima (northern Sudan) & 2 (both locally manufactured) \\
\hline Total & 15 \\
\hline
\end{tabular}

The maximum extractable monthly mean wind power per unit cross sectional area, $\mathrm{P}$, is given by:

$$
\mathrm{P}=0.3409 \mathrm{~V}^{3}
$$

Where:

$\mathrm{P}$ is the wind power $\mathrm{Wm}^{-2}$; and $\mathrm{V}$ is the average wind speed $\mathrm{ms}^{-1}$.

The amount of power extracted from the wind depends generally on the design of the wind rotor. In practice the wind machine power will be lost by the aerodynamic affects of the rotor. An important problem with wind pump system is matching between the power of the rotor, and that of the pump. In general the wind pump system consists of the following items:

- The wind rotor

- Transmission

- $\quad$ The pump 
The overall efficiency of the system is given by the multiplication of the rotor efficiency, transmission efficiency and the pump efficiency:

$$
\eta_{\text {overall }}=\eta_{\text {rotor }} \times \eta_{\text {transmission }} \times \eta_{\text {pump }}
$$

For wind pumps though efficiency is important, a more suitable definition is the number of gallons of water pumped per day per dollar. A sizing of wind pump for drinking and irrigation purposes usually requires an estimation of hourly, daily, weekly, and monthly average output. The method for making such estimation is combining data on the wind pump at various hourly average wind speeds with data from a wind velocity distribution histogram (or numerical information on the number of hours in the month that wind blows within predefined speed). The result is given in Table (9), which gives the expected output of wind pump in various wind speeds, and the statistical average number of hours that the wind blows within each speed range. Generally it is concluded that wind pump system have a potential to fulfil water lifting needs, both in Khartoum area and even in remote rural areas, both for irrigated agriculture and water supply for man and livestock. This conclusion is based on:

- Studies of several agencies dealing with the feasibility of wind pumps.

- The history of water pumping in the Gezira region for drinking purposes.

- The national policy of Sudan vis a vis wind energy.

Table 9. Wind speeds versus wind pump discharges

\begin{tabular}{|l|l|l|}
\hline Wind speeds $\left(\mathrm{ms}^{-1}\right)$ & Annual duration $(\mathrm{h})$ & Output rate $\left(\mathrm{m}^{3} \mathrm{~h}^{-1}\right)$ \\
\hline 3.0 & 600 & 0.3 \\
\hline 3.5 & 500 & 1.4 \\
\hline 4.0 & 500 & 2.3 \\
\hline 4.5 & 400 & 3.0 \\
\hline 5.0 & 500 & 3.7 \\
\hline 5.5 & 450 & 4.3 \\
\hline 6.0 & 450 & 4.7 \\
\hline 6.5 & 300 & 5.2 \\
\hline 7.0 & 300 & 5.7 \\
\hline
\end{tabular}

Sudan is rich in wind; mean wind speed of $4.5 \mathrm{~ms}^{-1}$ are available over $50 \%$ of Sudan, which is well suited for water lifting and intermittent power requirements, while there is one region in the eastern part of Sudan that has a wind speed of $6 \mathrm{~ms}^{-1}$ which is suitable for power production. In areas where there is wind energy potential but no connection to the electric grid the challenge is simplicity of design, and higher efficiency (Omer, 1998). Because of this potential for fulfilment of rural water pumping needs, it is recommended to continue the development of wind pumping in Sudan.

The research and development in the field of wind machines should be directed towards utilising local skills and local available materials. Local production of wind machines should be encouraged in both public and private organisations. The most obvious region to start with seems to be the northern regions because of a combination of:

- Favourable wind regime 
- Shallow ground water level 5-10 meters depth

- $\quad$ Existing institutional infrastructures

\subsection{Sustainable Development in Sudan}

Like most African countries, Sudan is vulnerable to climate variability and change. Drought is one of the most important challenges. The most vulnerable people are the farmers in the traditional rain-fed sector of western, central and eastern Sudan, where the severity of drought depends on the variability in amount, distribution and frequency of rainfall. Three case studies were conducted in Sudan as part of the project. They examined the condition of available livelihood assets (natural, physical, financial, human and social) before and after the application of specific sustainable livelihood environmental management strategies, in order to assess the capacity of communities to adapt creased resilience through access to markets and income generating opportunities. Figure 10 summarises oil production and consumption in Sudan.

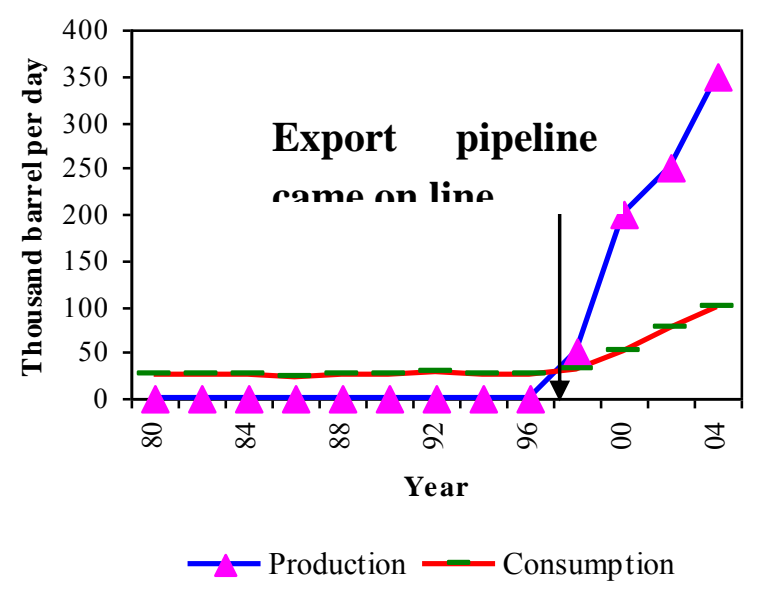

Figure 10. Sudan's oil production and consumption 1980-2005

\section{Conclusions}

There is strong scientific evidence that the average temperature of the earth's surface is rising. This is a result of the increased concentration of carbon dioxide and other GHGs in the atmosphere as released by burning fossil fuels. This global warming will eventually lead to substantial changes in the world's climate, which will, in turn, have a major impact on human life and the built environment. Therefore, effort has to be made to reduce fossil energy use and to promote green energies, particularly in the building sector. Energy use reductions can be achieved by minimising the energy demand, by rational energy use, by recovering heat and the use of more green energies. This study was a step towards achieving that goal. The adoption of green or sustainable approaches to the way in which society is run is seen as an important strategy in finding a solution to the energy problem. The key factors to reducing and controlling $\mathrm{CO}_{2}$, which is the major contributor to global warming, are the use of alternative approaches to energy generation and the exploration of how these alternatives are used today and may be used in the future as green energy sources. Even with modest assumptions about the availability of land, comprehensive fuel-wood farming programmes offer significant energy, economic 
and environmental benefits. These benefits would be dispersed in rural areas where they are greatly needed and can serve as linkages for further rural economic development. The nations as a whole would benefit from savings in foreign exchange, improved energy security, and socio-economic improvements. With a nine-fold increase in forest - plantation cover, a nation's resource base would be greatly improved. The international community would benefit from pollution reduction, climate mitigation, and the increased trading opportunities that arise from new income sources. The nontechnical issues, which have recently gained attention, include: (1) Environmental and ecological factors, e.g., carbon sequestration, reforestation and revegetation. (2) Renewables as a $\mathrm{CO}_{2}$ neutral replacement for fossil fuels. (3) Greater recognition of the importance of renewable energy, particularly modern biomass energy carriers, at the policy and planning levels. (4) Greater recognition of the difficulties of gathering good and reliable renewable energy data, and efforts to improve it. (5) Studies on the detrimental health efforts of biomass energy particularly from traditional energy users. Two of the most essential natural resources for all life on the earth and for man's survival are sunlight and water. Sunlight is the driving force behind many of the renewable energy technologies. The worldwide potential for utilising this resource, both directly by means of the solar technologies and indirectly by means of biofuels, wind and hydro technologies is vast.

\section{Acknowledgments}

The financial support for this research work from the Energy Research Institute is gratefully acknowledged. It is a pleasure to acknowledge, with gratitude, all those who, at different times and in different ways, have supported the development and evaluation of biomass energy technologies. A special thanks to my spouse Kawthar Abdelhai Ali for her support and her unwavering faith in me. Her intelligence, humour, spontaneity, curiosity and wisdom added to this article.

\section{References and Notes}

1. Abdeen, M. O. (2008). Chapter 10: Development of integrated bioenergy for improvement of quality of life of poor people in developing countries, In: Energy in Europe: Economics, Policy and Strategy- IB, Editors: Flip L. Magnusson and Oscar W. Bengtsson, 2008 NOVA Science Publishers, Inc., p.341-373, New York, USA.

2. Achard, P., and Gicqquel, R. (1986). European passive solar handbook. Brussels: Commission of the European Communities. 1986.

3. Bos, E., My, T., Vu, E., and Bulatao R. (1994). World population projection: 1994-95. Edition, published for the World Bank by the John Hopkins University Press. Baltimore and London.

4. Brain, G., and Mark, S. (2007). Garbage in, energy out: landfill gas opportunities for CHP projects. Cogeneration and On-Site Power 8 (5): 37-45. 2007.

5. Erlich, P. (1991). Forward facing up to climate change, in Global Climate Change and Life on Earth. R.C. Wyman (Ed), Chapman and Hall, London. 1991.

6. Herath, G. (1985). The green revolution in Asia: productivity, employment and the role of policies. Oxford Agrarian Studies. 14: 52-71.

7. International Energy Agency (IEA). (2007). Indicators for Industrial Energy Efficiency and $\mathrm{CO}_{2}$ Emissions: A Technology Perspective. 2007.

8. Jonathon, E. (1991). Greenhouse gardening. The Crowood Press Ltd. UK. 
9. John, W. (1993). The glasshouse garden. The Royal Horticultural Society Collection. UK.

10. Omer, A. M. (1997). Compilation and evaluation of solar and wind energy resources in Sudan. Renewable Energy 12 (1): 39-69.

11. Omer, A. M. (1998). Horizons of using wind energy and establishing wind stations in Sudan. Dirasat 25 (3): 545-552.

12. Omer, A.M., and Yemen, D. (2001). Biogas an appropriate technology. Proceedings of the $7^{\text {th }}$ Arab International Solar Energy Conference, P.417, Sharjah, UAE, 19-22 February 2001.

13. Omer, A. M. (2009a). Environmental and socio-economic aspect of possible development in renewable energy use, In: Proceedings of the $4^{\text {th }}$ International Symposium on Environment, Athens, Greece, 21-24 May 2009.

14. Omer, A. M. (2009b). Energy use, environment and sustainable development, In: Proceedings of the $3^{\text {rd }}$ International Conference on Sustainable Energy and Environmental Protection (SEEP 2009), Paper No.1011, Dublin, Republic of Ireland, 12-15 August 2009.

15. Omer, A. M. (2009c). Energy use and environmental: impacts: a general review, Journal of Renewable and Sustainable Energy, Vol.1, No.053101, p.1-29, United State of America, September 2009.

16. Omer, A. M. (2009d). Chapter 3: Energy use, environment and sustainable development, In: Environmental Cost Management, Editors: Randi Taylor Mancuso, 2009 NOVA Science Publishers, Inc., p.129-166, New York, USA, 2009.

17. Oxburgh, E.R. (1975). Geothermal energy. Aspects of Energy Conversion, p. 385-403. 1975.

18. Rawlings, R.H.D. (1999). Technical Note TN 18/99 - Ground Source Heat Pumps: A Technology Review. Bracknell. The Building Services Research and Information Association. 1999.

19. Robinson, G. (2007). Changes in construction waste management. Waste Management World, p. 43-49. 2007.

20. Sims, R.H. (2007). Not too late: IPCC identifies renewable energy as a key measure to limit climate change. Renewable Energy World 10 (4): 31-39. 2007.

21. Swift-Hook, D.T., et al. (1975). Characteristics of a rocking wave power devices. Nature 254: 504. 1975.

22. Trevor, T. (2007). Fridge recycling: bringing agents in from the cold. Waste Management World 5: 43-47. 2007.

23. United Nations (UN). (2001). World Urbanisation Prospect: The 1999 Revision. New York. The United Nations Population Division.

24. WCED. (1987). Our common future. New York. Oxford University Press.

(C) 2011 by the authors; licensee MDPI, Basel, Switzerland. This article is an open access article distributed under the terms and conditions of the Creative Commons Attribution license (http://creativecommons.org/licenses/by/3.0/). 